\title{
Analisis Level Metakognisi Siswa Sekolah Menengah Atas Penghafal al-Qur'an dalam Memecahkan Masalah Matematika
}

\author{
Dewi Rosikhoh $^{1}$, Liny Mardhiyatirrahmah ${ }^{2}$, Abdussakir $^{3}$ \\ ${ }^{1,2,3}$ Magister Pendidikan Matematika UIN Maulana Malik Ibrahim Malang \\ 1dewirosikhoh@gmail.com, ${ }^{2}$ linymardhiyatirrahmah@gmail.com, \\ ${ }^{3}$ sakir@mat.uin-malang.ac.id
}

\begin{tabular}{l}
\hline \hline Article Info \\
\hline Article history: \\
Received Sept $6^{\text {th }}, 2019$ \\
Revised Nov $14^{\text {th }}, 2019$ \\
Accepted Nov $15^{\text {th }}, 2019$ \\
\hline
\end{tabular}

Keywords:

Metacoginition Level;

Qur'an Memorizer;

Mathematics Problem

Metacognition has a key position on problem solving in mathematics. Metacognition is thinking about what they think. This research is qualitative research purposing for identifying of students' metacognition level on matematics problem solving based on their quatity juzs of Qur'an memorized. The subjects of this research is three students who are in $12^{\text {th }}$ grade in Senior High School. Students' metacognition level is identified through test and indicator of metacognition level. The result of research show that metacognition level of Senior High School students taking in level of aware use, semi strategic use and semi reflective use. The student who has less than 10 juzs in Qur'an memorized is in aware use level. The student who has 10 until less than 20 juzs in Qur'an memorized is in semi strategic use level. The student who has 20 until 30 juzs in Qur'an memorizing is in semi reflective use level. Based on this reasearch, researchers conclude that the more juzs memorized, the higher level that students get.

\section{Kata Kunci:}

Level Metakognisi; Penghafal al-Qur'an; Masalah Matematika

\section{Abstrak}

Metakognisi memiliki peran penting dalam pemecahan masalah matematika. Metakognisi adalah berpikir tentang apa yang dipikirkan. Penelitian ini adalah penelitian kualitatif yang bertujuan untuk mengidentifikasi level metakognisi siswa berdasarkan kuantitas hafalan al-Qur'an dalam memecahkan masalah matematika. Subjek penelitian adalah tiga siswa Sekolah Menengah Atas (SMA) kelas XII yang hafal al-Qur'an. Level metakognisi siswa diidentifikasi dengan 
104| Rosikhoh, Mardhiyatirrahmah, dan Abdussakir: Analisis Level Metakognisi Siswa Sekolah...

menggunakan lembar tes dan data karakteristik metakognisi. Hasil penelitian menunjukkan bahwa level metakognisi siswa SMA berdasarkan kuantitas hafalan al-Qur'an dalam memecahkan masalah matematika berada di level aware use, semi strategic use, dan semi reflective use. Siswa dengan kategori jumlah hafalan kurang dari 10 juz berada pada level aware use, siswa kategori jumlah hafalan mulai dari 10 hingga kurang dari 20 juz berada pada level semi strategic use, sedangkan siswa kategori jumlah hafalan mulai dari 20 sampai dengan 30 juz berada pada level semi reflective use. Berdasarkan hasil analisis level metakognisi, peneliti menyimpulkan bahwa semakin banyak jumlah hafalan al-Qur'an, maka level metakognisinya juga semakin tinggi.

\section{PENDAHULUAN}

Pemecahan masalah merupakan bagian dari kurikulum matematika yang sangat penting karena dalam proses pembelajaran, siswa dimungkinkan memperoleh pengalaman menggunakan pengetahuan serta keterampilan yang sudah dimiliki untuk diterapkan pada pemecahan masalah yang bersifat tidak rutin (Afrida \& Handayani, 2018). Salah satu proses yang harus ada dalam matematika adalah pemecahan masalah (Cahyani \& Setyawati, 2016). Proses pemecahan masalah ini berfungsi untuk membentuk pengetahuan matematika baru, menyelesaikan masalah lainnya yang berkaitan dengan pengetahuan sebelumnya, mencoba dan beradaptasi dengan berbagai strategi dalam memecahkan masalah, serta memantau dan merefleksikan dalam proses memecahkan masalah matematika ((NCTM), 2000). Fungsi inilah yang menjadi alasan utama untuk siswa memiliki kemampuan pemecahan masalah karena kemampuan tersebut merupakan kompetensi dasar dalam belajar matematika (Cahyani \& Setyawati, 2016).

Berbagai hasil penelitian menunjukkan bahwa peningkatan kemampuan dalam pemecahan masalah disebabkan karena kemampuan metakognisi siswa (Chairani, 2015). Aktivitas memantau dan merefleksikan dalam proses pemecahan masalah matematika sebenarnya menampilkan apa yang dipikirkan siswa untuk menyelesaikan 
permasalahan (Pramono, 2017). Kesadaran siswa dalam memikirkan apa yang mereka pikirkan dan kemampuan untuk memantau proses mereka sendiri dalam memecahkan masalah dikenal dengan kemampuan metakognisi (Laurens, 2010). Metakognisi membantu siswa untuk menyelesaikan permasalahan, mengetahui dengan jelas dan benar mengenai permasalahan yang akan diselesaikan, dan mengerti bagaimana menemukan solusi atau jawaban dari permasalahan yang ada (Kuzle, 2013). Penelitian lain yang dilakukan oleh Danang Setiyadi menunjukkan bahwa aktivitas metakognisi terbukti muncul ketika siswa berusaha untuk memecahkan masalah matematika (Setyadi, 2017).

Kemampuan metakoginisi ini sendiri memiliki level-level yang bisa diraih siswa ketika ia memecahkan permasalahan matematika. Level ini dikemukakan oleh Laurens dan terdiri dari tactic use, aware use, semi strategic use, strategic use, semi reflective use, dan reflective use (Laurens, 2010). Tactic use adalah suatu bentuk pemikiran dimana siswa tidak menyadari apa dan mengapa pemikiran tersebut digunakan untuk memecahkan masalah. Aware use biasanya mendeskripsikan siswa dapat menggunakan pemikirannya dalam memecahkan masalah dan menyadari apa yang dipikirkannya tersebut. Semi strategic use mengacu pada siswa yang mampu mengarahkan pemikirannya dengan menyadari ada strategi atau cara yang digunakan untuk memecahkan masalah maupun strategi untuk meningkatkan ketepatan berpikirnya. Strategic use mendeskripsikan siswa yang secara sadar mampu menggunakan berbagai strategi untuk meningkatkan ketepatan berpikirnya. Semi reflective use merupakan level yang mendeskripsikan siswa mampu melakukan perefleksian berpikir selama proses memecahkan masalah tetapi tidak dilakukan secara menyeluruh. Reflective use mendeskripsikan bahwa siswa mampu merefleksikan pemikirannya sebelum, selama, dan sesudah ia memecahkan masalah serta proses ini selalu dilakukannya (Setyadi, 2017).

Level kemampuan metakognisi ini sendiri terkait dengan kemampuan otak untuk berpikir dan memutar ulang pengetahuan sebelum ia memecahkan suatu masalah matematika. Suatu penelitian menunjukkan 
106| Rosikhoh, Mardhiyatirrahmah, dan Abdussakir: Analisis Level Metakognisi Siswa Sekolah...

bahwa kemampuan berpikir tingkat tinggi siswa dipengaruhi oleh aktivitas menghafal al-Qur'an (Pamungkas Stiyamulyani \& Sri Jumini, 2018). Menghafal al-Qur'an sendiri menuntut penghafal untuk tetap harus ingat dengan hafalan sebelumnya meski ia menambah hafalan baru. Penghafal al-Qur'an juga dituntut untuk menemukan berbagai strategi yang tepat bagi mereka sendiri agar tetap bisa mengingat keseluruhan ayat (Hidayah, 2016). Umumnya, semakin banyak ayat yang dihafal, semakin cepat dan mudah untuk menghafal ayat-ayat lainnya (Stiyamulyani, 2018). Hal ini mengindikasikan bahwa terjadi proses perbaikan konsentrasi dan strategi untuk terus menghafal menjadi semakin tinggi, apabila semakin banyak ayat-ayat al-Qur'an yang dihafal (Pamungkas Stiyamulyani \& Sri Jumini, 2018).

Kegiatan menghafal al-Qur'an dikatakan berpengaruh terhadap Higher Order Thinking Skill (HOTS) oleh Pamungkas Setyamulyani (2018). Meskipun metakognisi merupakan bagian dari HOTS namun, dalam penelitiannya yang dilakukan secara kuntitatif, Pamungkas tidak membahas secara khusus hubungan level metakognisi dengan kegiatan menghafal al-Qur'an. Penelitian mengenai analisis level metakognisi terdahulu, adalah mengaitkan level metakognisi dengan penggolongan kemampuan skor matematika pada tingkat rendah, sedang dan tinggi (Setyadi, 2017; Mahromah, 2013; Fitriyah, 2013). Berdasarkan hal tersebut, peneliti belum menemukan penelitian yang mengaitkan level metakognisi dengan kuantitas hafalan al-Qur'an yang dimiliki oleh siswa. Oleh karena itu, peneliti tertarik untuk menganalisis secara kualitatif mengenai kuantitas hafalan al-Qur'an terhadap level metakognisi penghafal al-Qur'an.

\section{METODE PENELITIAN}

Metode penelitian yang digunakan adalah metode penelitian kualitatif, karena berlandaskan filsafat postpositivisme yang digunakan untuk meneliti pada kondisi objek yang alamiah, analisis data bersifat induktif, dan hasil penelitiannya lebih menekankan pada makna (Sulaiman, 2018). Penelitian ini menggunakan soal tes berbentuk essay 
yang telah diuji validitas dan reliabilitasnya yang diambil dari penelitian Danang Setyadi (2017).

Subjek penelitian diambil dengan menggunakan teknik Purposive Sampling, yakni memilih tiga siswa SMA kelas XII yang hafal al-Qur'an. Setiap siswa mewakili satu kategori kuantitas hafalan, yaitu kurang dari10 juz, 10 juz sampai kurang dari 20 juz, serta 20 juz sampai dengan 30 juz.

Pada proses analisis data, peneliti melakukan reduksi data dengan menyeleksi, memfokuskan, dan menyederhanakan hasil tes berdasarkan data karakteristik level metakognisi yang telah dikemukakan oleh Danang Setyadi (2017). Penarikan kesimpulan mencakup pencarian arti dan makna data serta memberi penjelasan. Hasil analisis data dijadikan data untuk menentukan adanya keterkaitan level metakognisi siswa terhadap hafalan al-Qur'annya.

Tabel 1. Karakteristik Metakognisi Subjek pada Setiap Level Metakognisi (Setyadi, 2017) Level Tactic Use

1. Sekedar melakukan perhitungan dari sebagian yang diketahui soal.

2. Suatu keputusan untuk memecahkan masalah tanpa memikirkan kembali tentang keputusan tersebut.

3. Tidak mengetahui bahwa apa yang dia tulis tidak bermakna.

Level Aware Use

1. Secara sadar menemukan dan menggunakan cara untuk memecahkan masalah.

2. Mengungkapkan mengapa dan bagaimana pemikiran tersebut digunakan untuk memecahkan masalah.

3. Memberikan alasan terhadap keputusan atau langkah yang diambil.

4. Tidak melakukan pengecekan kembali setelah menemukan jawaban.

\section{Level Semi Strategic Use}

1. Melakukan pengecekan terhadap apa yang dipikirkannnya.

2. Mencoba menunjukkan ketepatan berpikirnya dengan melingkari hasil yang diperoleh.

3. Mengalami keraguan terhadap hasil yang diperolehnya. 
108| Rosikhoh, Mardhiyatirrahmah, dan Abdussakir: Analisis Level Metakognisi Siswa Sekolah...

4. Menyadari adanya kesalahan, tetapi tidak tahu bagaimana memperbaiki kesalahan tersebut.

\section{Level Strategic Use}

1. Menyadari bahwa ia harus membaca soal secara berulang-ulang untuk memahami masalah.

2. Melakukan perhitungan ulang ketika menyadari adanya kesalahan.

3. Mengalami keraguan terhadap hasil yang diperoleh dan mencoba melakukan perhitungan kembali dengan cara yang lain untuk meyakinkannya.

4. Membandingkan pekerjaannya dengan informasi yang sudah ia ketahui.

5. Menunjukkan ketepatan apa yang dipikirkannya dengan melingkari atau menggarisbawahi jawaban.

6. Menggunakan berbagai cara atau strategi untuk memecahkan masalah.

7. Meyakini hasil yang diperoleh benar setelah melakukan pengecekan dengan menggunakan cara yang lain.

\section{Level Semi Reflective Use}

1. Memikirkan kembali pengetahuan terdahulu yang dapat digunakan untuk memecahkan masalah.

2. Mencoba-coba.

3. Mengecek kembali apa yang dipikirkannya.

4. Merefleksikan pemikirannya pada saat memecahkan masalah.

5. Menunjukkan kemampuannya dalam memberikan argumen pendukung pemikirannya.

6. Meyakini hasil yang diperoleh benar.

7. Tidak melakukan perhitungan ulang (mengecek kembali) setelah menemukan hasil akhir.

8. Melakukan perefleksian berpikir setelah menemukan jawaban akhir meskipun hanya terbatas pada proses menemukan jawaban.

9. Tidak melakukan pengecekan kembali setelah menemukan hasil akhir.

10.Tidak melakukan perefleksian setelah menemukan jawaban akhir. 


\section{Level Reflective Use}

1. Menganalisis masalah sebelum menyelesaikannya.

2. Merencanakan strategi pemecahan dengan menggunakan kasus yang lebih sederhana.

3. Memikirkan kembali rencana yang telah dibuat dan menggunakan strategi lain (menghitung secara manual) untuk meningkatkan ketepatan berpikirnya.

4. Memikirkan kembali efektivitas dari strategi yang digunakan untuk melakukan penjumlahan dan mengambil suatu keputusan setelah melakukan penilaian tersebut.

5. Memikirkan kembali cara yang ia gunakan dan hasil yang diperoleh setelah menyelesaikan masalah

6. Memikirkan kembali efektivitas dari strategi yang digunakan untuk memecahkan masalah.

7. Merefleksikan pemikirannya selama dan sesudah menyelesaikan masalah.

\section{HASIL PENELITIAN DAN PEMBAHASAN}

Proses pemecahan masalah matematika yang dilakukan siswa melibatkan aktivitas kognisi dan metakognisi. Berikut ini adalah proses pemecahan masalah masing-masing subjek tersebut.

Subjek UA mewakili kategori jumlah hafalan kurang dari 10 juz. Pada tahap awal ia menggambar suatu lingkaran dan 18 titik yang terletak di dalam lingkaran tersebut seperti pada Gambar 1. Hal tersebut menunjukkan bahwa subjek UA mengalami aktivitas perencanaan kognitif.

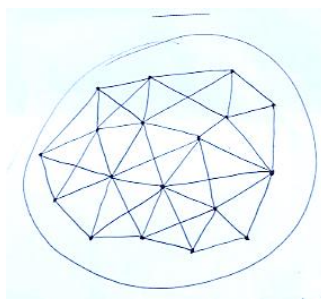

Gambar 1. Lingkaran Memuat 18 Titik yang Digambar oleh Subjek UA 
110| Rosikhoh, Mardhiyatirrahmah, dan Abdussakir: Analisis Level Metakognisi Siswa Sekolah...

Selanjutnya, ia membuat garis yang menghubungkan titik-titik tersebut. Ia menemukan 46 garis. Percobaannya tersebut membawa subjek UA menuliskan alasan bahwa garis-garis tersebut masih dapat dihubungkan lagi satu sama lain. Subjek UA mengambil kesimpulan bahwa jumlah garis lurus yang terbentuk adalah tak terbatas. Hal ini menunjukkan bahwa subjek UA secara sadar menemukan dan menggunakan cara untuk menyelesaikan masalah dan memberikan alasan terhadap keputusan atau langkah yang diambil. Pada tahap ini, terlihat bahwa subjek UA mengalami aktivitas metakognisi. Namun pada kesimpulan, ia tidak melakukan pengecekan kembali setelah menemukan jawaban (Gambar 2). Berdasarkan karakteristik level metakognisi, subjek UA masuk dalam level Aware Use.

Subjek AK mewakili kategori jumlah hafalan mulai dari 10 sampai kurang dari 20 juz. Subjek AK memulai memecahkan masalah dengan mengalami aktivitas kognisi, yaitu menggambar suatu lingkaran dan 18 titik di dalam lingkaran tersebut (Gambar 2).

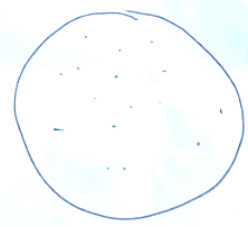

\section{Gambar 2. Lingkaran dan 18 Titik yang Digambar oleh Subjek AK}

Pada tahap berikutnya, ia menggambar lagi lingkaran dan 18 titik di dalam lingkaran yang dilengkapi dengan garis yang menghubungkan antar titik-titik tersebut (Gambar 3).

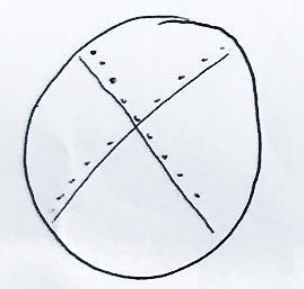

Gambar 3. Lingkaran dan 18 Titik Terhubung yang Digambar oleh Subjek AK 
Mungkin subjek AK mengalami keraguan terhadap hasil yang diperolehnya, atau mungkin juga ia menyadari adanya kesalahan, tetapi tidak tahu bagaimana memperbaiki kesalahan tersebut. Hal ini ditunjukkan dengan percobaannya, subjek AK yang mencoba menggambar ulang lingkaran dengan 18 titik dengan teknik penarikan garis secara berbeda seperti pada Gambar 4 dan 5.

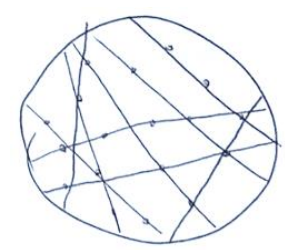

\section{Gambar 4. Lingkaran dan 18 Titik Terhubung II yang Digambar oleh Subjek AK}

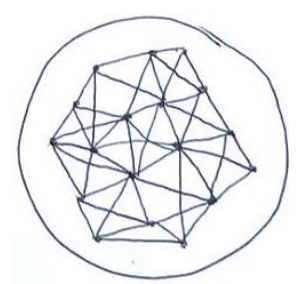

\section{Gambar 5. Lingkaran dan 18 Titik Terhubung III yang digambar oleh Subjek AK}

Setelah melakukan percobaan menggambar 4 (empat) kali, subjek AK menemukan 48 garis. Namun demikian, subjek AK berargumen bahwa garis-garis tersebut masih bisa disambungkan satu sama lain. Sehingga subjek AK mengambil kesimpulan bahwa jumlah garis yang terbentuk adalah tak hingga. Melihat dari 4 (empat) kali percobaan, subjek AK menyadari adanya kesalahan, tetapi tidak tahu bagaimana memperbaiki kesalahan tersebut. Berdasarkan karakteristik level metakognisi, subjek AK tergolong pada level Semi Strategic Use.

Subjek HR mewakili kategori jumlah hafalan mulai dari 20 sampai dengan 30 juz. Subjek HR mengawali proses kognitifnya dengan menghitung titik yang dihasilkan jika ia menghubungkan titik-titik yang ada. Hal ini terlihat pada Gambar 6. Selain menghubungkan titiknya, ia 
juga menyimpulkan dari percobaan menggambarnya bahwa jika sebanyak $n$ titik maka ada $n$ garis yang dihasilkan. Proses ini masuk dalam bagian melakukan perefleksian setelah menemukan jawaban tetapi hanya pada bagian tertentu.
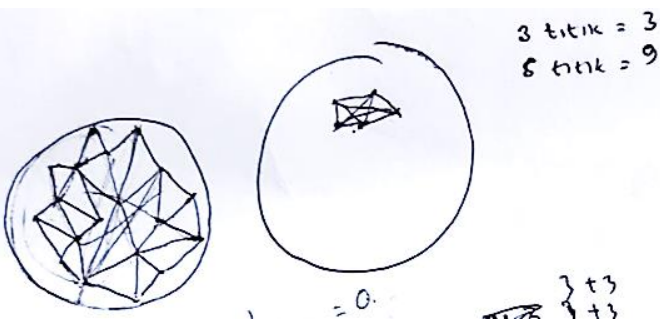

\section{Gambar 6. Lingkaran dan Perhitungan Sebanyak $n$ Titik yang Menghasilkan $n$ Garis}

Setelah itu, subjek HR nampaknya mulai bisa menganalisis bahwa titik-titik yang dihubungkan ini dapat menghasilkan garis-garis yang berpola pada barisan matematika. Oleh karena itu, ia mulai menggunakan pengetahuan matematika yang ia dapatkan sebelumnya untuk menemukan dengan mudah berapa banyak garis yang dapat dibuat tanpa harus menggambarnya. Ia juga mengecek setiap langkah yang dilakukannya dan langsung melakukan revisi jika ada kesalahan. Hal ini termasuk dalam proses memikirkan kembali langkah yang digunakan sebelumnya dengan mengulangi proses menemukan cara yang digunakan serta melakukan revisi jika ada kesalahan (Gambar 7).

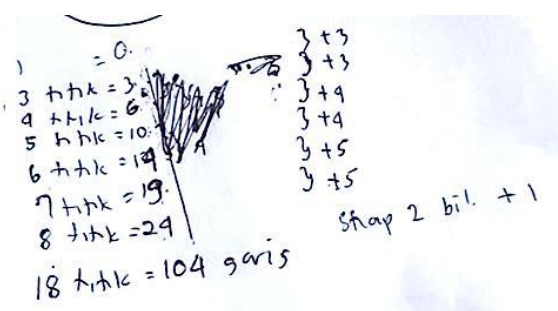

Gambar 7. Perhitungan Titik dan Garis Menggunakan Rumus Barisan Matematika 
Proses selanjutnya yang dilakukan subjek HR adalah mencocokkan atau membuktikan jawaban akhir. Hal ini terlihat pada Gambar 8. Subjek HR melakukan peninjauan jawaban akhirnya dengan menggunakan cara lain, yaitu mencoba dengan menggambarnya. Hal ini dilakukan untuk meyakinkan bahwa deret matematika yang didapatkan memang sesuai dengan hasil percobaan Gambarnya.

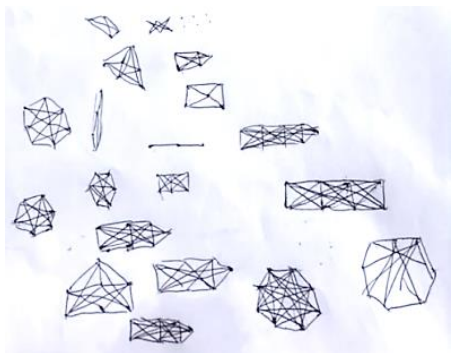

\section{Gambar 8. Pengecekan Kembali dengan Menggambar Garis-garis}

Kemudian, subjek HR mengambil keputusan terhadap proses kognitifnya setelah ia melakukan perefleksian terhadap hasil awal yang ia peroleh. Pada tahap ini, subjek HR meyakini bahwa hasil yang diperolehnya benar setelah melakukan pengecekan sebelumnya. Hal ini terlihat jelas pada Gambar 9.

$$
\begin{aligned}
& \text { 1 thth }=0 \text { garis } 3+3 \\
& 3 \text { thk }=3 \text { gans } 3+3 \\
& 9 \text { titik }=6 \begin{array}{ll}
6 & \text { gars } \\
10 & \text { gais }
\end{array}+4 \\
& 5 \text { hith }=10 \text { gais } j+4 \\
& 6 \text { xhik }=14 \text { garis } 3+5 \\
& \begin{array}{l}
7 \text { hak }=19 \text { garis } 3 \text { yois } \\
8 \text { htok }=24 \text { yois }
\end{array} \\
& 18 \text { thk }=104 \text { ganis }
\end{aligned}
$$

\section{Gambar 9. Simpulan Akhir yang diambil oleh Subjek HR}

Setelah melakukan percobaan menggambar berkali-kali dan melakukan perhitungan deret matematika, subjek HR menyimpulkan bahwa 18 titik dalam lingkaran dapat diperoleh 104 garis. Subjek HR 
dapat diketahui bahwa ia cukup menguasai konsep matematika yang muncul dari persoalan yang diberikan. Ia juga mampu merencanakan strategi untuk menyelesaikan permasalahan dengan memberikan kasus yang lebih sederhana. Tak hanya itu, ia begitu teliti jika ia melakukan kesalahan dalam menyelesaikan permasalahan. Subjek HR bahkan menggunakan cara lain untuk membuktikan bahwa perhitungan yang dilakukannya sudah benar, yaitu melalui percobaan menggambar garisgaris tersebut. Meskipun begitu, sujek HR hanya melakukan perefleksian terbatas untuk satu cara saja dan dengan tujuan untuk mencari jawaban yang benar. Tak hanya itu, HR juga kurang dalam melakukan pengecekan berulang-ulang untuk membuktikan kebenaran jawabannya, sehingga jawaban yang didapatnya adalah salah. Berdasarkan pada karakteristik level metakognisi, subjek HR tergolong pada level Semi Reflective Use.

Berdasarkan analisis di atas, ditemukan bahwa siswa yang memiliki kuantitas hafalan lebih tinggi, memiliki level metakognisi yang lebih tinggi. Hal ini terlihat dari subjek UA (hafal al-Qur'an kurang dari 10 juz) ditemukan berada pada level aware use, subjek AK (hafal al-Qur'an mulai dari 10 juz sampai kurang dari 20 juz) berada pada level semi strategic use, dan subjek HR (hafal al-Qur'an mulai dari 20 juz sampai dengan $30 \mathrm{juz}$ ) berada pada level semi reflective use.

Temuan ini sejalan dengan temuan dari dua hasil penelitian terdahulu yang dilakukan oleh Fitriyah (2013) dan Mahromah dan Manoy (2013) yang menunjukkan bahwa semakin tinggi kemampuan kognisi yang dimiliki siswa, semakin tinggi juga level metakognisi siswa tersebut. Namun temuan ini juga bertentangan dengan hasil penelitian Setyadi (2017) yang menyatakan bahwa siswa yang memiliki kemampuan kognisi lebih tinggi belum tentu memiliki level metakognisi yang lebih tinggi. Dalam penelitian Danang Setyadi (2017) ditemukan subjek yang sampai pada level tertinggi yakni level reflective use. Sedangkan pada penelitian ini, subjek dengan kuantitas hafalan terbanyak hanya sampai pada level semi reflective use. Namun, dalam penelitian ini, peneliti belum menemukan subjek dengan kuantitas hafalan 30 juz.

Penelitian ini juga sesuai dengan penelitian Nuqthy Faiziyah (2018) yang menemukan adanya korelasi antara jumlah hafalan al-Qur'an 
dengan prestasi belajar siswa. Sehingga ia menyimpulkan bahwa jumlah hafalan al-Qur'an memberikan kontribusi terhadap prestasi belajar siswa. Penelitian lain yang sejalan adalah penelitian Pamungkas Stiyamulyani dan Sri Jumini (2018) yang menyatakan bahwa ada pengaruh aktivitas menghafal AlQuran terhadap Higher Order Thinking Skill (HOTS). Selanjutnya, Stiyamulyani dan Sri Jumini (2018) juga mengatakan apabila anak-anak telah hafal juz 'Amma dan surat al-Baqarah saja, dan ia bisa membacanya dengan fasih dan lancar tanpa mushaf, berarti konsentrasinya sudah bertahan lama, apalagi hafal 30 juz sebelum dewasa. Konsentrasi yang tinggi sangat berpengaruh dalam kecerdasan berfikir. Semakin tinggi konsentrasinya semakin tuntas berfikirnya. Hal ini berarti semakin banyak kuantitas hafalan al-Qur'annya, maka kemampuan metakognisinya juga akan semakin baik.

\section{SIMPULAN}

Berdasarkan hasil penelitian, dapat disimpulkan bahwa level metakognisi siswa berdasarkan kuantitas hafalan al-Qur'an dalam memecahkan masalah matematika terdiri atas aware use, semi strategic use, dan semi reflective use. Siswa dengan kategori jumlah hafalan di bawah 10 juz berada pada level aware use, dan siswa kategori jumlah hafalan mulai dari 10 sampai kurang dari 20 juz berada pada level semi strategic use, sedangkan siswa kategori jumlah hafalan mulai dari 20 sampai dengan 30 juz berada pada level semi reflective use. Berdasarkan hasil analisis level metakognisi, peneliti menemukan bahwa semakin banyak jumlah hafalan al-Qur'an dari siswa, maka level metakognisinya juga semakin tinggi.

Penelitian ini masih bisa dikuatkan dengan melakukan penelitian lebih besar dengan memilih subjek penelitian yang lebih banyak dan bervariasi dari tingkatan kelas serta dapat dilengkapi dengan artikel metakognisi lainnya agar peneliti dapat benar-benar mengetahui isi pikiran siswa ketika mencoba memecahkan masalah matematika yang diberikan. 
116| Rosikhoh, Mardhiyatirrahmah, dan Abdussakir: Analisis Level Metakognisi Siswa Sekolah...

\section{DAFTAR PUSTAKA}

Afrida, A. N., \& Handayani, S. (2018). Meningkatkan Kemampuan Pemecahan Masalah Matematika dan Rasa Ingin Tahu Siswa Kelas XI Melalui Model ARIAS. PRISMA, Prosiding Seminar Nasional Matematika, 1, 33-39. Retrieved from https://journal.unnes.ac.id/sju/index.php/prisma/.

Cahyani, H., \& Setyawati, R. W. (2016). Pentingnya Peningkatan Kemampuan Pemecahan Masalah Melalui PBL untuk Mempersiapkan Generasi Unggul Menghadapi MEA. PRISMA, Prosiding Seminar Nasional Matematika, 151-160. Retrieved from https://journal.unnes.ac.id/sju/index.php/prisma/article/view/21635.

Chairani, Z., \& Anda, K. (2015). Perilaku Metakognisi Siswa dalam Pemecahan Masalah Matematika. Math Didactic: Jurnal Pendidikan Matematika 1(3). $\quad$ Retrieved from https://jurnal.stkipbjm.ac.id/index.php/math/article/view/20.

Faiziyah, N. (2018). Memorizing Qur'an and Mathematics Achievement. Mathematics Education Journal. Retrieved from https://doi.org/10.22219/mej.v2i1.5800.

Fitriyah, R. (2013). Identifikasi Level Metakognitif Siswa MA Muhammadiyah 1 Malang dalam Memecahkan Masalah Matematika. Unpublished Thesis. Malang: University of Muhammadiyah Malang.

Hidayah, N. (2016). Strategi Pembelajaran Tahfidz Al-Qur'an di Lembaga Pendidikan. Ta'allum: Jurnal Pendidikan Islam, 4(1), 6381. Retrieved from https://doi.org/10.21274/taalum.2016.4.1.63-81.

Kuzle, A. (2013). Patterns of Metacognitive Behavior During Mathematics Problem-Solving in a Dynamic Geometry Environment. International Electronic Journal of Mathematics Education. 8 (1) Retrieved from https://www.iejme.com/article.

Laurens, T. (2010). Penjenjangan Metakognisi Siswa yang Valid dan Reliabilitas. Jurnal Pendidikan dan Pembelajaran (JPP). 17 (2) Retrieved from http://journal.um.ac.id/index.php/pendidikan-danpembelajaran/article/view/3212.

Mahromah, L. A. dan Manoy, J. T. (2013). Identifikasi Tingkat Metakognisi Siswa dalam Memecahkan Masalah Matematika Berdasarkan Perbedaan Skor Matematika. MATHEdunesa, 2(1). Retrieved from http://jurnalmahasiswa.unesa.ac.id/ index.php/mathedunesa/article/view/1208), diakses 08 April 2019. 
(NCTM), N. C. of T. of M. (2000). Principles and Standards for School Mathematics. Reston: VA: NCTM.

Pamungkas Stiyamulyani, P. S., \& Sri Jumini, S. J. (2018). Pengaruh Menghafal Al-Qur'an Terhadap High Order Thinking Skill (HOTS) Ditinjau dari Motivasi Berprestasi Mahasiswa. SPEKTRA: Jurnal Kajian Pendidikan Sains. Retrieved from https://doi.org/10.32699/spektra.v4i1.43.

Pramono, A. J. (2017). Aktivitas Metakognitif Siswa SMP dalam Pemecahan Masalah Matematika Berdasarkan Kemampuan Matematika. Kreano, Jurnal Matematika Kreatif-Inovatif. Retrieved from https://doi.org/10.15294/kreano.v8i2.6703.

Setyadi, Danang. (2017). Identifikasi Level Metakognisi Siswa dalam Memecahkan Masalah Matematika pada Materi Barisan. Tesis tidak diterbitkan: Universitas Negeri Malang.

Setyadi, D. (2017). Metacognition Process of Students Class X Senior High School in Mathematic Problem Solving. IOSR Journal of Research \& Method in Education. Retrieved from https://doi.org/10.9790/7388-0705070107.

Sulaiman, S. (2018). Paradigma dalam Penelitian Hukum. Kanun : Jurnal Ilmu Hukum, 20(2), 255-272. Retrieved from https://doi.org/10.24815/kanun.v20i2.10076. 
118| Rosikhoh, Mardhiyatirrahmah, dan Abdussakir: Analisis Level Metakognisi Siswa Sekolah... 